THURSDAY, NOVEMBER 27,1873

\section{THE SOUTHERN UPLANDS OF SCOTLAND *}

II.

THE next member of the series of rocks making up the upper Llandeilo series in the Southern Uplands has received from the officers of the Scotch Geological Survey the name of the Lowther group. In its typical area, which is in the N.W. of Dumfriesshire, this group is composed of "fine grey shales and finely laminated felspathic greywackes with occasional grit beds." The estimated thickness of this group amounts to 5,000 feet. It is seen overlying the Haggis rock group in the streams which drain the upper portion of the Lowther hills; with the underlying Haggis Rock group it forms a synclinal trough in which the Lowther hills are contained.

In Wigtonshire the Lowther group rests upon the Dalveen group. The strata here generally correspond with those of Dumfriesshire, but shales are less abundant, and flagstones and grit with shale bands become more developed. In this county, however, the proportion of the fine and coarse rocks of this group varies in different localities. 'The rocks of the Lowther group in Wigtonshire are best exposed on the shores of the Irish Channel. Here between Morroch Bay and Knockienausk Head, cliffs are seen from 100 to 300 feet high composed of strata often very twisted and broken, belonging to the Lowther group; and in the higher portion of this group, where the flags are well developed, they have been worked for roofing and flooring purposes.

Above the Lowther group, and forming the highest member of the Upper Llandeilo series, as these occur in the Southern Uplands, are strata composed of grey shales with bands of fine-grained blue greywacke and finty mudstones. Numerous bands of dark anthracitic shales with graptolites interstratify these rocks. These strata, with their associated anthracitic beds, have received the name of the "Upper Black Shale Group." Their estimated thickness is about 3,400 feet. This Upper Black Shale group occurs near the northern limits of the Upper Llandeilo rocks, and is more abundantly developed in Lanarkshire than in Dumfriesshire.

The Upper Black Shale group, in its typical area, has yielded the officers of the Geological Survey a rich graptolitic fauna, no less than 27 species having been obtained from this series of rocks. These species bear a very close resemblance to such as occur in the Moffat Shales, a horizon much below the Upper Black Shale group in position. Two Brachiopods have also been found in connection with these Upper Black Shales, viz., Siphonotreta micula, a form also occurring in the Moffat Shales, and likewise in the Upper Llandeilo rocks of Wales, especially in the neighbourhood of Builth; and a Discina which has not yet been specially recognised.

The Upper Black Shales group, following the persistent strike of the Upper Llandeilo rocks of the Southern Uplands of Scotland, makes its appearance in Wigtonshire. Two bands of this group lying in a synclinal trough traverse the portion of Wigtonshire contained in Sheet 3 . One of these bands is well seen in Morroch Bay, about a mile and a half south-east of Port Patrick. The other appears south-west of Stranraer, and crossing the moors to the north-east, is seen in the bed of the Luce below Cairnarzean. In Morroch Bay the Upper Black Shale group exhibits a threefold petrological nature. The higher beds consist of thin black shales, having in them lenticular masses and seams of coarse clay, ironstone, and nodular layers of greywacke and pyritous kernals. The strata here are much crumpled, and intrusive masses and veins of felstone have invaded them. It is in this upper portion of the group that graptolites occur, but the number of species obtained from these strata is considerably under what have been found in the Upper Black Shale group of Lanarkshire.

The representatives of the Upper Llandeilo rocks in the Southern Uplands of Scotland attain to a very great thickness. Of the lower portion of the series, the Ardwell group, the Lower or Moffat Black shale group, the Queenberry grit group, the Hartfell group, and the Daer group, the officers of the Geological Survey have not given their thickness in Dumfriesshire. Of the other four groups, the Dalveen, the Haggis Rock, the Lowther and the Upper Black Shales, these have an estimated thickness of $13,000 \mathrm{ft}$. If to this amount be added the five groups below, we have a development of Upper Llandeilo strata in the south of Scotland which must amount to nearly $20,000 \mathrm{ft}$. This great thickness of strata much exceeds the same series of rocks developed elsewhere in the British Isles.

The Upper Llandeilo rocks of the Southern Uplands of Scotland have a greater uniformity in their mineral nature than is usually common to the series. Greywacke in the form of shales, sandstones, grit, and conglomerates, having in some of their sub-divisions black shales containing graptolites, constitute this great thickness of sedimentary rocks. There is an absence of limestone strata, only nodules occurring occasionally, and the calcareous flags which are so characteristic of this portion of the Lower Silurian in its typical area Llandeilo, have no representatives in the South of Scotland. The rocks in this district have been originally greyish and reddish muds, grey and purple sands, and pebble-beds, with occasionally dark carbonaceous muds, which may have derived their black colour either from decaying sea-weeds or decomposing Hydrozoa. The presence of carbonate of lime seems to have been very rare in the Upper Llandeilo seas of the areas which are now recognised as the Southern Uplands, during the deposition of their strata, and to this great absence of carbonate of lime we may probably attribute the absence of some of the fossils which are so abundant in Wales in this series of rocks. Graptolites are essentially the characteristic fossils of the Upper Llandeilo of the Southern Uplands. The same species seem to run through whole strata from the Moffat Shales to the highest mem. ber of the series, having a range of probably $18,000 \mathrm{ft}$.; and many of these forms of graptolites are common alike to the Upper Llandeilo rocks of Wales and Scotland.

The case is, however, very different when we comie to compare the crustacea of the two regions. In Scotland. the Upper Llandeilo crustaceans are very few, and almost confined to Phyllopods, being Peltocaris Harknessi, $P$. aptychoides, and Disinocaris Brownii, while in Wales we have a considerable development of trilobitic life. Of the 
latter only one specimen, in the form of a tail, has yet been obtained from the Upper Ilandeilo strata of the South of Scotland; and this specimen is too imperfect to admit of its being specifically determined. With reference to molluscs, these are nearly equally rare in the Southern Uplands. Only two Brachiopods have hitherto been recognised, while many forms appertaining to several genera have been obtained from the Welsh Upper Llandeilo strata. Notwithstanding the paucity of varied forms of organic remains in the Upper Llandeilo rocks of the Southern Uplands, their rich graptolitic fauna is at once indicative of their age, and the absence of other forms is most probably referable to want of calcareous strata in connection with these deposits.

The labours of the officers of the Geological Survey among the highly contorted and crumpled rocks of the Southern Uplands have afforded further information, were such required, of the causes from whence cleavage results. In a country so subject to flexures and contortions, where anticlinal axes and synclinal folds have been inverted, we should naturally look for abundant evidence of the superinduced structures from which true slates have derived their origin. The great mass of the Upper Llandeilo rocks of the South of Scotland rarely furnishes anything in the form of slates proper; and when we consider the nature of these rocks, which consist for the most part of greywacke sandstones and grits, we camnot fail to discover that the cause of the general absence of cleavage from these rocks has arisen from their petrological naturc, The officers of the Survey have, however, in several instances, pointed out the recurrence of cleavage among the finer shales; and this occurrence usually accompanies violent contortions of the strata.

Although rocks of an Upper Llandeilo age enter so largely into the composition of the Southern Uplands, they are not the exclusive representatives of the Lower Silurian rocks in this area; above the Upper Llandeilo strata rocks referabie to the Bala or Caradoc age occur. These Caradoc rocks, which occupy a very small area when contrasted with the Upper Llandeilo strata, are marked in the Southern Uplands by a feature which is unknown to their occurrence elsewhere. They are unconformable to the underlying Upper Llandeilo beds, a circumstance which Prof. Geikie well describes as "a new feature in the geology of Britain." The Caradoc rocks have not been recognised in Wigtonshire. They are described in connection with Sheet 15 . They occur in a trough extending from Wedder Dod N.E. at least as far as the hills on the right bank of the Clyde, below Abington in Lanarkshire.

Here they are seen as greywackes, "passing on the one hand into a crumbling sandstone, and on the other into pebbly grits, with shale partings and with beds of conglomerate found chiefly at their base." In one spot a little concretionary limestone is seen, "the only example of limestone met with in the Lower Silurian rocks in Sheet 15." This limestone has afforded no fossils, but the conglomerates and the pebbly and gitty beds higher up in the series are abundantly fossiliferous. Denudation has probably removed some higher beds from this group. Its total thickness amounts to about i,700 feet.

From the Caradoc rocks of the Lead Hills the geological surveyors have obtained a good series of fossils.
We miss from their list the whole of the graptolites so abundant in and so characteristic of the Upper Llandeilo strata. In their place we have corals, trilobites, many forms of brachiopods, two lamellibranchiates, several gasteropods, and an arthorceras. Most of the species are characteristic Caradoc forms ; but they have associated with them some which occur also in the Llandovery series.

The Southern Uplands of Scotland have other mem. bers of the great Silurian series besides those which have been referred to. These occur along a portion of the south-east flanks of the range, and consist of rocks having a general resemblance to the greywacke strata which form so large a part of the Upper Llandeilo rocks in the South of Scotland. The newer Silurian strata occurring on the south-east margin have, however, a very distinct series of fossils ; and associated with their shales are found calcareous concretions frequently affording organic remains; the greywackes flaggy beds also in this higher group often contain fossils, especially graptolites. These graptolites belong to species occupying a much higher horizon than the forms which make their appearance in the Upper Llandeilo rocks; and the organic remains derived from the calcareous nodules also indicate strata higher in position than the Caradoc series. The rocks of an Upper Silurian age are well developed on the shores of the Stewarty of Kirkcudbright, especially on the eastern side of the mouth of the Dee. They occur also in Dumfriesshire, being seen near the southern margin of the Silurians at Dalton Mill, in the parish of Dalton, where the flaggy strata yield the same forms of graptolites which occur near the mouth of the Dee; and they have been extensively recognised in Roxburghshire.

As contrasted with the nearest area where Silurian rocks occur in England, the strata and the organic remains of the Southern Uplands of Scotland show great dissimilarity.

The distance of the nearest portion of the area where Silurian rocks are seen in England from the south-east side of the South of Scotland strata of the same series does not exceed 30 miles; for the northern flank of the Caldbeck range in Cumberland is not greater than this, in distance from the axis of the Lower Silurian rocks in Dumfriesshire where the Ardwell group occurs.

The Lake district of the north of England, occupied principally by Silurian rocks, exhibits strata of a lower position than any of the Silurian deposits of the Southern Uplands. These lower rocks of the Lake district are the Skiddaw slates of Prof. Sedgwick, which in many localities contain graptolites.

The facies of this graptolitic fauna is, however, widely different from that of the graptolitic fauna of the Upper Llandeilo rocks of the south of Scotland. In the Lake district there are no strata which can be paralleled with the Upper Llandeilo rocks. Above the Skicldaw slates of the north-west of England there occur great accumulations of igneous rocks in the form of traps, ashes, traptuffs and similar volcanic products. And it is only when the highest of these rocks is reached, which appear to have resulted from sub-aërial volcanic action, that strata occur in which organic remains are met with.

These strata, the Coniston limestones and their associated shales, are prolific in fossils of a nature indicative of the Caradoc age. 
It is difficult to conceive how all traces of the vast igneous action which occurred within the distance of 30 miles from the Scottish Silurian area should be absent from the rocks of the Southern Uplands. The unconformability of the Caradoc deposits on the Upper Llandeilo strata in the Southern Uplands may perhaps afford some clue to this difficulty. The Skiddaw slates were probably ancient land in the area now occupied by the Lake district during the period of the deposition of the Upper Llandeilo rocks of the south of Scotland. This ancient land seems to have been subject to violent sub-aërial volcanic action, being the earlier epoch of the Caradoc series. During the later portion of the same epoch this violent volcanic action ceased, the area covered with igneous products again subsided beneath the sea, and allowed of the accumulation of the materials of the Coniston limestone and the succeeding groups.

In the Southern Uplands of Scotland the well-marked break recognised by the officers of the Survey points to a lapse of time between the deposition of the highest of the Upper Llandeilo groups and the conglomerates at the base of the Caradoc rocks. It is probably during this lapse of time that volcanic action was so rife on the other side of what is now the Solway Firth. This lapse of time is stinl further indicated by the comparative small development of the Caradoc rocks of the South of Scotland, as contrasted with those of the typical Caradoc areas of Shropshire and Wales, and also by their fossil contents, which indicate that only a portion of the group is represented in this area, and that this portion appertains to the upper part of the series.

From what has been said it will be apparent that the labours of the officers of the Geological Survey of Scotland have put us in possession of most important information concerning the very difficult series of rocks making up the strata of the bulk of the Southern Uplands. There are other matters amply detailed in the "Explanatory Memoirs" such as the metamorphism which the Silurian. rocks bave in some places undergone, and the intrusive rocks which are associated with them. The Old Red Sandstones as laid down in Sheet 15 are fully described. The important carboniferous areas of New Cumnock and Guelt, of Lugar and Muirkirk, and of Glespin or Douglas Water, with their thin limestone and low coal, are largely detailed. In relation to Dumfriesshire, the Sanquhar coal-field, made up of strata belonging to the true coal measures, and the carboniferous rocks which underlie it are also fully described. The Permian rocks of a portion of the Nith basin, having porphyries in different beds at their base, and brick-red sandstones with trapean detritus forming their upper portion, and also rocks of the same age occurring on the shore near Corsewall House, Wightonshire, are subjects treated of in the Memoirs. Igneous rocks of an age posterior to the Permian are also referred to. Superficial deposits in the condition of drift sands, and gravels, brick clays, and erratic blocks, also still more recent products in the form of raised sea beaches, blown sands, peat and alluvium are fully alluded to. Finally the explanations afford information concerning the economic minerals of the several districts, the whole containing a record of an amount of careful observations and inferences such as could only have been arrived at by the labour and experience of such a staff of officers as that which constitutes the Geological Survey.

ROBERT HARKNESS

\section{LEYBOLD'S EXCURSTON TO THE ARGEN. TINE PAMPAS}

Escursion a las Pampas Arjentindis : hojas de mi diario: Febrero de I871: Seguido de tablas de observaciones baromètricas, un boceto de la muta tomaan. Por Federico Leybold. 8vo, pp. Io8. (Santiago, 1873.)

7 HE publication of a book relating to Natural History 1 in Chili is a rare event, and therefore well worthy of record. Except Philippi and Landbecls's "Catalago de las Aves Chilenas," and some few papers by the same authors in the "Anales" of the University of Santiago, the present is almost the first that has come before our notice. And these, it must be recollected, are not the productions of native Chilians, but of me nbers of the allpervading Teutonic race, who have brought their science with them from their distant fatherland.

Herr Leybold, or Don Federico Leybold, as we suppose we must call him, for he writes in Spanish, has been long resident in Santiago, and active in inrestigating every branch of Natural History in his adopted country. During the last few years, as he tolls us in the introductory chapter of the present work, he has sent six expeditions over the Andes to explore the natural riches of the "Argentine Tempe," and finally in the month of February of I87I was able to make arrangements to proceed himself upon a collecting tour into the same district. The route taken from Santiago was up the valley of the Maipo, to the junction with it of the "Valle del Yeso," and thence up this morthern branch to the foot of the "Portillo de los Piuquenes," where the watershed was crossed. But a second and more elevated pass-the "Portillo Mendocino"-succeeds on this route over the main chain, which is, we believe, that usualiy taken to Mendoza. From the summit the descent was made over the elevated eastern slopes of the Mindozan Andes to an estancia called Vistafiores, situated at the foot of the range, which was made the headquarters of the party while they explored the surrounding country. Rainy weather and drunken servants much hindered operations during the stay at this place, which appears only to have lasted about a week, when it was determined to return to Santiago by the more southern "Paso del Diamante." This pass leads under the volcano of Maips into the main valley of the Maipo, and this enabled the travellers to join their former route after about a weels's difficult and occasionally dangerous travel amid the snows and storms of the higher Andes.

Herr Leybold's diary of this interesting month's excursion is replete with notes and observations in every branch of Natural History-Zoology, Botany, and Geology. Bircis, beetles, and plants appear to have engaged his chief attention-but other objects are not passed unnoticed. Not only are frequent references given to known species observed in the Andes and on the adjacent districts of the Argentine Republic, but descriptions are introduced of species believed to be new to science, and discovered on this occasion. Thus we have characterised 